\title{
PERGESERAN KEWENANGAN MUI DALAM MEMBERIKAN JAMINAN PRODUK HALAL PASCA LAHIRNYA UNDANG-UNDANG NOMOR 33 TAHUN 2014
}

\author{
Meta Suriyani \\ Fakultas Hukum Universitas Samudra \\ J1. Merandeh-Langsa-Aceh, 24415 \\ metasuriyani179@yahoo.com
}

\begin{abstract}
Abstrak, Upaya Pemerintahan Indonesia dalam memberikan jaminan kehalalan produk yang beredar di masyarakat, telah melahirkan Undang-Undang Nomor 33 Tahun 2014tentangJaminan Produk Halal. Namun Pasca lahirnya Undang-Undang Nomor 33 Tahun 2014tentangJaminan Produk Halal telah terjadi pergeseran kewenangan, dimana sebelumnya Majelis Ulama Indonesia (MUI) memilki kewenangan yang sangat besar (super body) meliputi pemeriksaan pangan, penetapan danpenerbitan sertifikat halal dan lainnyaberdasarkan Keputusan Menteri Kesehatan Nomor 924/MENKES/SK/VIII/1996, Keputusan Menteri Agama Nomor 518 Tahun 2001 tentang Pedoman dan Tata Cara Pemeriksaandan Penetapan Pangan Halal, dan Keputusan Menteri Agama Nomor 519 Tahun 2001 Tanggal 30 Nopember 2001 tentangLembaga Pelaksana Pemeriksaan Pangan Halal, sehingga telah bergeser menjadi kewenangan pemerintah yaitu Lembaga Pemeriksa Halal (LPH) dan Badan Penyelenggara Jaminan Produk Halal (BPJPH) di bawah Kementrian Agama yang dalam pelaksanaannya bekerjasama dengan Majelis Ulama Indonesia.
\end{abstract}

Kata Kunci : Pergeseran, Kewenangan, Jaminan Produk Halal.

Abstract, The Indonesian Government's efforts in providing halal product guarantee that circulated in the community, has spawned Law No. 33 of 2014 on Halal Product Guarantee. However, after the birth of Law No. 33 of 2014 on Halal Product Guarantee there has been a shift of authority, where previously the Indonesian Ulema Council (MUI) has very large authority (super body) including food inspection, determination and issuance of halal certificate and others based on Ministerial Decree Health No. 924 / MENKES / SK / VIII / 1996, Decree of the Minister of Religious Affairs No. 518/2001 on Guidelines and Procedures for the Inspection and Stipulation of Halal Food, and Decree of the Minister of Religious Affairs No. 519 of 2001 dated 30 November 2001 concerning Implementing Agency for Halal Food Inspection, Has shifted to the authority of the government, namely the Halal Inspection Agency $(\mathrm{LPH})$ and the Halal Product Guarantee Organizer (BPJPH) under the Ministry of Religious Affairs which in its implementation in cooperation with the Indonesian Ulema Council.

Keywords: Shifting, Authority, Halal Product Guarantee

\section{Pendahuluan}

Di era teknologi modern, konsumen semakin tidak bisa lagi membedakan sepintas suatu makanan halal atau haram. Perkembangan ilmu pengetahuan dan teknologi (IPTEK) serta perubahan sosial yang begitu cepat, terutama di kota-kota besar di mana penduduknya padat dan terjadi perubahan pola hidup, menyebabkan konsumen ingin 
efisien dalam mengkonsumsi makanan. Mereka butuh makanan yang mudah disajikan, berselera, bertahan segar dengan warna, aroma, rasa dan tekstur yang diinginkan.

Dengan IPTEK, semua itu dapat diwujudkan. Untuk itu diperlukan berbagai zat tambahan pangan dalam memproses makanan yang dapat dibuat secara kimiawi atau dari hewan. Hal ini menyebabkan peluang terjadinya perubahan makanan dari halal menjadi tidak halal semakin besar.Untuk menghindari hal-hal yang tidak diinginkan, maka setiap konsumen perlu berhati-hati sebelum membeli suatu produk pangan yang akan dikonsumsinya. ${ }^{1}$ Pada sisi lain, para konsumen baik di pasar nasional maupun internasional dewasa ini semakin kritis menuntut standarisasi produk yang semakin tinggi dan kompleks, yang tidak hanya menyangkut aspek mutu, kesehatan dan lingkungan akan tetapi juga menuntut aspek sosial budaya dan agama.

Indonesia dengan penduduknya yang mayoritas Islam, tentunya sangat berkepentingan untuk mengetahui halal atau tidaknya pangan yang di beli dan akan dikonsumsinya.Undang-Undang Dasar Negara Republik Indonesia Tahun 1945 (UUD 1945) memberikan dasar-dasar konstitusional bagi seluruh warganegara Indonesia dalam menjalani kehidupan, baik duniawi maupun ukhrowi. Dalam menjalankan hubungan manusia dengan manusia, setiap orang pada saat yang bersamaan tidak dapat melepaskan diri dari pengaruh dengan Tuhan-Nya sebagaimana dijumpai secara maknawi dalam norma filosofis negara yaitu Pancasila.

Setiap warga negara Republik Indonesia dijamin hak konstitusional oleh UUD 1945 seperti hak asasi manusia, hak beragama dan beribadat, hak mendapat perlindungan hukum dan persamaan hak dan kedudukan dalam hukum, serta hak untuk memperoleh kehidupan yang layak termasuk hak untuk mengkonsumsi pangan dan menggunakan produk lainnya yang dapat menjamin kualitas hidup dan kehidupan manusia. Pangan dan produk lainnya yang ada di bumi baik melalui proses alamiah, mekanisme produksi, maupun melalui rekayasa genetik tidak dapat dikonsumsi secara bebas oleh manusia tanpa batas. Pembatasan tersebut bukan saja terhadap yang diharamkan, akan tetapi yang dihalalkanpun ada pembatasannya dari Allah SWT. ${ }^{2}$

Hal tersebut sejalan dengan Firman Allah SWT dalam Al-Qur'an, Surat Albaqarah ayat 168 yang artinya : "Hai sekalian manusia, makanlah yang halal lagi baik dari apa yang terdapat di bumi, dan janganlah kamu mengikuti langkah-langkah syaitan; karena Sesungguhnya syaitan itu adalah musuh yang nyata bagimu”. Hadist Nabi Muhammad SAW, "Dari Abu ABdillah Nu'man bin Basyir r.a,"Saya mendengar Rasulullah SAW bersabda, yang artinya "Sesungguhnya yang halal itu jelas dan yang haram itu jelas. Di antara keduanya terdapat perkara-perkara yang syubhat (samar-samar) yang tidak diketahui oleh orang banyak.Maka, barang siapa yang takut terhadap syubhat, berarti dia telah menyelamatkan agama dan kehormatannya. Dan barang siapa yang terjerumus dalam perkara syubhat, maka akan terjerumus dalam perkara yang diharamkan.

\footnotetext{
${ }^{1}$ Hernawan, Pentingnya Pencantuman Label Halal Dalam Kemasan Produk Pangan Sebagai Bentuk Perlindungan Hukum Bagi Konsumen Muslim, (Skripsi), (Samarinda: Fakultas Hukum Universitas 17 Agustus 1945, 2013), hlm. 17-18

${ }^{2}$ Tulus abadi, Tim Pengkajian Hukum Tentang Peran Serta Masyarakat Dalam Pemberian Informasi Produk Halal, (Jakarta : Kementerian Hukum Dan Hak Asasi Manusia RiBadan Pembinaan Hukum Nasional, 2011), hlm. 1-2
} 
Sebagaimana penggembala yang menggembalakan hewan gembalaannya di sekitar (ladang) yang dilarang untuk memasukinya, maka lambat laun dia akan memasukinya. Ketahuilah bahwa setiap raja memiliki larangan dan larangan Allah adalah apa yang Dia haramkan. Ketahuilah bahwa dalam diri ini terdapat segumpal daging, jika dia baik maka baiklah seluruh tubuh ini dan jika dia buruk, maka buruklah seluruh tubuh.Ketahuilah bahwa dia adalah hati” (HR. Bukhari dan Muslim).

Oleh karena itu, dalam memenuhi kebutuhan pangan dan produk lainnyaseseorang harus memenuhi juga tuntunan agama.Begitu pula pelaku usaha dalam memproduksi dan/atau memperdagangkan barang dan/atau jasa wajib berstandar kehalalan menurut ketentuan agama Islam. Sebagaimana dalam Pasal 8 ayat (1) huruf $h$ dan ayat (4) Undang-Undang Nomor 8 Tahun 1999 tentang Perlindungan Konsumen dinyatakan Pelaku usaha dilarang memproduksi dan/atau memperdagangkan barang dan/atau jasayang : tidak mengikuti ketentuan berproduksi secara halal, sebagaimana pernyataan "halal"yang dicantumkan dalam label;Pelaku usaha yang melakukan pelanggaran pada ayat (1) dan ayat (2) dilarangmemperdagangkan barang dan/atau jasa tersebut serta wajib menariknya dari peredaran. ${ }^{3}$

Oleh karena itu pula, Pemerintah Indonesia terus berupaya untuk memberikan jaminan kehalalan terhadap setiap produk yang beredar di masyarakat. Sehingga bagi konsumen sendiri salah satu upaya yang pertama kali dapat dilakukan terhadap produkproduk yang beredar di masyarakat adalah dengan melihat kemasan dan labelnya. Label pada kemasan produk pangan bukanlah sekedar hiasan.Dari label inilah, konsumen mengetahui banyak hal tentang produk yang akan dikonsumsinya. Upaya Pemerintahan Indonesia dalam memberikan jaminan kehalalan produk tersebut, telah melahirkan Undang-Undang Nomor 33 Tahun 2014Tentang Jaminan Produk Halal. Namun Pasca lahirnya Undang-Undang Nomor 33 Tahun 2014TentangJaminan Produk Halal telah terjadi pergeseran kewenangan dari Majelis Ulama Indonesia (MUI) kepada Pemerintah, dimana sebelumnya pemeriksaan pangan halal, penerbitan sertifikat halal ${ }^{4}$ dan label halal ${ }^{5}$ merupakan kewenangan Majelis Ulama Indonesia berdasarkan Keputusan Menteri Kesehatan Nomor 924/MENKES/SK/VIII/1996, Keputusan Menteri Agama Nomor518 Tahun 2001 tentang Pedoman dan Tata Cara Pemeriksaandan Penetapan Pangan Halal, dan Keputusan Menteri Agama Nomor 519 Tahun 2001 Tanggal 30 Nopember 2001 tentangLembaga Pelaksana Pemeriksaan Pangan Halal.

Berdasarkan uraian tersebut, menarik untuk ditelusuri lebih lanjut Pelaksanaan jaminan produk halal sebelum lahirnya Undang-Undang Nomor 33 Tahun 2014.

\footnotetext{
${ }^{3}$ Lihat Pasal 62 ayat (1) Undang-Undang Republik Indonesia Nomor 8 Tahun 1999 tentang Perlindungan Konsumen, Pelaku usaha yang melanggar ketentuan sebagaimana dimaksud dalam Pasal 8, Pasal 9, Pasal 10, Pasal 13 ayat (2), Pasal 15, Pasal 17 ayat (1) huruf a, huruf b, huruf c, huruf e, ayat (2), dan Pasal 18 dipidana dengan pidana penjara paling lama 5 (lima) tahun atau pidana denda paling banyak Rp 2.000.000.000,00 (dua miliar rupiah).

${ }^{4}$ Sertifikat Halal adalah pengakuan kehalalan suatu Produk yang dikeluarkan oleh BPJPH berdasarkan fatwa halal tertulis yang dikeluarkan oleh MUI.Lihat Pasal 1 angka 10 UndangUndang Nomor 33 Tahun 2014TentangJaminan Produk Halal

${ }^{5}$ Label Halal adalah tanda kehalalan suatu Produk. Lihat Pasal 1 angka 11 Undang-Undang Nomor 33 Tahun 2014TentangJaminan Produk Halal
} 
Volume 14, Nomor 1, Januari-Juni 2019

Pergeseran kewenangan MUI dalam memberikan jaminan produk halal pasca lahirnyaUndang-Undang Nomor 33 Tahun 2014.

\section{Metode Penelitian}

Penelitian ini merupakan jenis penelitian yuridis normatif. Adapun dalam membedahpermasalahan ini dilakukan dengan pendekatan yang meliputi pendekatan perundang-undangan(statute approach), pendekatan asas, pendekatan kasus (the case approach), pendekatan konsep, pendekatan perbandingan,dan pendekatan analisis. Spesifikasi penelitian yang digunakan berupa deskritif analisis.Data yang digunakan adalah data sekunder meliputi peraturan perundang-undangan dan literatur yang relevan dengan pembahasan.Data diolah secara comprehensive, all inclusive dan systematic dengan analisis normatif kualitatif.

\section{Pembahasan}

\section{Pelaksanaan Jaminan Produk Halal Sebelum Lahirnya Undang-Undang Nomor 33 Tahun 2014.}

Setiap produsen harus memenuhi kebutuhan dan hak konsumen, termasuk konsumen Muslim. Memproduksi produk halal adalahbagian dari tanggungjawab perusahaan kepada konsumen muslim.Di Indonesia, untuk memberikan keyakinan kepada konsumenbahwa produk yang dikonsumsi adalah halal, maka perusahaanperlu memiliki Sertifikat Halal MUI. ${ }^{6}$ Sejarah MUI menerbitkan sertifikat halal yaitu berawal dari sebuah kasus yang menghebohkan terjadi tahun 1988, Buletin Canopy edisi Januari tahun itu yang diterbitkan oleh Senat Mahasiswa Fakultas Peternakan Universitas Brawijaya (UB)-Malang memuat tulisan berupa laporan penelitian Ir. Tri Susanto, M.App.Sc yang menyatakan bahwa sejumlah produk makanan dan minuman terindikasi mengandung lemak babi. Saat itu almarhum adalah mantan guru besar Teknologi Pangan Universitas Brawijaya Malang.Tulisan tersebut telah menimbulkan kepanikan masyarakat baik dari kalangan konsumen muslim khususnya, maupun kalangan produsen produk pangan. Sejumlah produsen mengalami penurunan omset secara drastis. PT Sanmaru Food Manufacture, produsen Indomie mengaku penjualannya turun 20-30 persen dari omset 40 juta bungkus perbulannya. Penjualan Kecap ABC melorot hingga 20 persen, dan Es Krim Campina yang sempat dikait-kaitkan dengan penelitian tersebut turun hingga 40 persen. ${ }^{7}$

Produsen Biskuit Siong Hoe, PT Tri Fabig terpaksa harus gencar mengiklankan diri bila produknya tidak haram. PT Food Specialties Indonesia (FSI)

\footnotetext{
${ }^{6}$ Anonimous, Panduan Umum Sistem Jaminan Halal Lppom - MUI, Lembaga Pengkajian Pangan Obat-Obatan Dan Kosmetika, (Jakarta : Majelis Ulama Indonesia, 2008), hlm. 7.

7 Aisjah Girindra, LPPOM MUI Pengukir Sejarah Sertifikasi Halal. (Jakarta: LPPOM MUI, 2005), hlm. 39-40 dan Thobieb al-Asyhar, Bahaya Makanan Haram. (Jakarta: Al Mawardi Prima, 2003), hlm. 9-10
} 
terpaksa juga mengeluarkan dana iklan Rp 340 juta, jumlah yang cukup besar ketika itu.Fenomena sebagaimana di atas menyadarkan berbagai fihak bahwa keberadaan jaminan halal untuk produk-produk konsumsi menjadi suatu kebutuhan yang mendesak bagi umat Islam. Seperti disampaikan oleh Profesor Amin Aziz ketua LPPOM MUI periode pertama, anggapan bahwa jika umat Islam mayoritas pasti masalah halal akan terjamin ternyata tidak otomatis, sehingga dibutuhkan adanya kebijakan yang mengatur.Kebutuhan jaminan produk halal telah menjadi isu penting di Indonesia. Umat Islam yang menjadi penduduk mayoritas dengan jumlah sekitar $86 \%$ bisa terusik dengan isu halal-haram ini sehingga menuntut adanya penyikapan dari pemerintah.Sekalipun demikian pemerintah ketika itu tidak segera mengambil kebijakan cepat menyikapi fenomena tersebut.Sikap yang dilakukan pemerintah justru berusaha menetralisir masalah dengan secara yang kurang proporsional. Seperti yang ditampilkan oleh Sekjen Departemen Agama (ketika itu) Tarmidzi Taher, yang secara demonstratif meminum susu di sebuah pabrik di Pasuruan untuk diliput oleh media dengan maksud meredam gejolak di masyarakat.

Majelis Ulama Indonesia (MUI) yang menyatakan dalam pedoman organisasinya sebagai wadah musyawarah para ulama, para zuama (pemimpin), dan cendekiawan muslim akhirnya yang mengambil inisiatif untuk melakukan sejumlah pertemuan membahas masalah tersebut. Upaya yang dilakukan oleh MUI tidak lepas dari dorongan para intlektual muslim dan para ulama.MUI merupakan organisasi non pemerintah tetapi karena sifatnya sebagai organisasi forum lintas ormas, keberadaannya dipandang strategis sehingga mempunyai kedekatan khusus dengan pemerintah.Dari pertemuan-pertemuan yang diselenggarakan MUI ini akhirnya terbentuk Lembaga Pengkajian Pangan, Obat-obatan, dan Kosmetika, Majelis Ulama Indonesia yang kemudian disingkat LPPOM MUI.

LPPOM MUI berdiri tanggal 6 Januari 1989 berdasarkan Surat Keputusan Majelis Ulama Indonesia Nomor: Kep./18/MUI/I/1989, dengan rencana kegiatan utama melaksanakan pemeriksaan produk halal yang kemudian disebut sertifikasi halal.Kegiatan sertifikasi halal ini dimaksudkan untuk mendapatkan jaminan produk halal. Proses sertifikasi halal dilakukan dengan cara penelusuran mendalam untuk mengetahui secara pasti apakah bahan-bahan yang digunakan dalam pembuatan suatu produk pangan serta proses produksinya telah terjamin halal dan konsisten atau tidak. Hasil sertifikasi halal adalah diterbitkannya sertifikat halal bila telah memenuhi syarat yaitu pernyataan halal atas suatu produk yang dihasilkan oleh suatu perusahaan berdasarkan hasil audit dan kajian fatwa. Adanya sertifikat halal dimaksudkan agar konsumen muslim terlindungi dari produk-produk yang tidak halal.

Kendatipun LPPOM MUI telah berdiri sejak tahun 1989, namun dalam implementasinya sertifikat halal dikeluarkan pertama kali oleh MUI berdasarkan hasil audit dari LPPOM MUI baru tahun 1994 setelah LPPOM MUI memperoleh persetujuan dari Menteri Agama ketika itu. Selama waktu sekitar lima tahun sejak berdiri sampai dapat direalisasikannya kegiatan sertifikasi halal.Pemerintah kendatipun tidak secara khusus menetapkan kebijakan berkaitan dengan jaminan produk halal, bersamaan dengan berdirinya LPPOM MUI akhirnya juga 
mengeluarkan kebijakan yang searah dengan peran dan tugas yang dikerjakan oleh LPPOM MUI. Adanya proses sinkronisasi kebijakan yang dilakukan oleh pemerintah tidak lepas dari peran Majelis Ulama Indonesia.

MUI yang secara konsisten menggulirkan pentingnya jaminan produk halal melalui sertifikasi halal.Hal ini bisa dicermati bahwa ketika terjadi isu halal haram yang mengancam stabilitas perekonomian, pemerintah tidak serta merta mengambil langkah cepat menyikapi hal ini, justru MUI yang kemudian mengambil inisiatif dan akhirnya melahirkan LPPOM MUI.Sinkronisasi kebijakan yang dilakukan pemerintah diawali dari adanya penandatanganan piagam kerjasaman antara Departemen Kesehatan, Departemen Agama dan Majelis Ulama Indonesia pada tanggal 21 Juni 1996. Setelah penandatanganan piagam tersebut Departemen Kesehatan mengeluarkan Surat Keputusan Nomor 924/MENKES/SK/VIII/1996 yang disahkan tanggal 30 Agustus 1996 sebagai perubahan atas Surat Keputusan Menteri Kesehatan No. 82/MENKES/SK/I/1996.

Pada SK Menkes No. 82/MENKES/SK/I/1996, pemerintah telah mengatur label halal untuk produk yang akan dijual di toko-toko pengecer, namun ijin label diberikan atas dasar keterangan sepihak dari perusahaan terkait dengan ingredient bahan-bahan yang digunakan, sehingga kebijakan label halal seperti ini tidak bisa efektif memberikan jaminan halal pada masyarakat.Ketentuan pada No. 82/MENKES/SK/I/1996 ini merupakan kelanjutan dari keputusan bersama Menteri Kesehatan dan Menteri Agama RI No. 427/Men.Kes /SKB/VIII/1985 - No.68 Tahun 1985 tentang Pencantuman Tulisan Halal Pada Label Makanan. Ketentuan inilah yang kemudian diubah dengan SK Menkes No. 924/MENKES/ SK/VIII/1996.

Dalam SK Menkes No. 924/MENKES/SK/VIII/1996 ini secara lengkap dinyatakan bahwa persetujuan pencantuman tulisan "halal" diberikan oleh Dirjen POM berdasarkan fatwa dari Komisi Fatwa Majelis Ulama Indonesia".SK Menkes No. 924/MENKES/SK/VIII/1996 ini merupakan peraturan pertama yang mengatur pencantuman label halal berdasarkan sertifikat halal dari MUI. Kebijakan ini berlanjut sampai dengan saat ini. Bersamaan dengan dihilangkannya Direktorat Jenderal Pengawasan Obat dan Makanan (Ditjen POM) keberadaannya diganti dengan Badan Pengawas Obat dan Makanan (BPOM) yang bertanggungjawab langsung kepada Presiden sesuai dengan Kepres Nomor 166 Tahun 2000, tugas Ditjen POM terkait dengan labelisasi halal secara otomatis digantikan oleh BPOM. ${ }^{8}$

Kemudian tahun 2001, Menteri Agama mengeluarkan ketentuan yaitu Keputusan Menteri Agama R.I. Nomor 518 Tahun 2001 Tanggal 30 Nevember 2001 tentangPedoman dan Tata Cara Pemeriksaan dan Penetapan Pangan Halal. Keputusan Menteri Agama ini terbentuk didasarkan pada alasan melalui konsiderannya bahwa dalam rangka memberikan kepastian kehalalan pangan yang dikemas dan diperdagangkan di Indonesia, dipandang perlu menindaklanjuti ketentuan Pasal 11 ayat (2) Peraturan Pemerintah Nomor 69 Tahu 1999 tentang

\footnotetext{
${ }^{8}$ Ainul Yaqin, Sekretaris Umum MUI Jawa Timur, https://www.hidayatullahlm. com/kajian/sejarah/read/2017/01/18/109939/sejarah-sertifikasi-halal-di-indonesia-1.html dan melalui Arif Kurnia, https://www.hpainternational.org/2017/03/06/sejarah-lppom-mui-dansertifikasi-halal-di-indonesia/, diunduh tanggal 1 april 2017.
} 
Label dan Iklan Pangan; bahwa sehubungan dengan butir a di atas, perlu ditetapkan Pedomanan dan Tata Cara Pemeriksaan dan Penetapan Pangan Halal, dengan Keputusan Menteri.

Sehingga Keputusan Menteri Agama ini pula mengatur tentang sertifikat halal dan label halal yaitu dalam hal pangan yang diperiksa Lembaga Pemeriksa telah memenuhi persyaratanpangan halal dan telah difatwakan halal, Lembaga Pemeriksa menerbitkan Sertifikat Halal. Sertifikat Halal, berlaku selama 2 (dua) tahun dandapat diperbarui untuk jangka waktu yang sama sesuai peraturan perundang-undanganyang berlaku. Sertifikat halal dapat dicabut oleh Lembaga Pemeriksa apabila produsen atau importir pemegang Sertifikat tersebut melakukanpelanggaran di bidang pangan halal sebagaimana diatur dalam peraturan perundang-undanganyang berlaku. ${ }^{9}$

Lembaga Pemeriksa berhak melakukan pemeriksaan mendadak kepada produsen atauimportir pemegang Sertifikat Halal.Jika dikemudian hari terjadi perubahan proses produksi, bahan baku, bahan tambahan,atau bahan penolong, Auditor Halal Internal wajib segera melapor kepada LembagaPemeriksa untuk dievaluasi dan diperoleh persetujuan sebelum digunakan. ${ }^{10}$ Produsen atau importir yang telah memperoleh Sertifikat Halal, wajib mencantumkanLabel Halal pada kemasan produknya.Dalam Label Halal wajib dicantumkan nomorSertifikat Halal dan tulisan "Halal" dengan huruf arab dan huruf latin.Label Halal, wajib dibuat dalam bentuk yang tidak mudah rusak dan tidak dapat dipalsukan, serta dalam ukuran tertentu.Menteri Agama menetapkan perusahaan percetakan yang mampu membuat Label. ${ }^{11}$

Lembaga Pemeriksa yang maksud berdasarkan Keputusan Menteri Agama R.I. Nomor 518 Tahun 2001 tanggal 30 Nevember 2001 tentangPedoman dan Tata Cara Pemeriksaan Dan Penetapan Pangan Halal yang berwenang menerbitkan Sertifikat Halal kemudian ditegaskan berdasarkan Keputusan Menteri Agama Republik Indonesia Nomor 519 Tahun 2001 Tanggal 30 Nopember 2001 tentang Lembaga Pelaksana Pemeriksaan Pangan Halal, yang menyatakan bahwa menunjuk Majelis Ulama Indonesia sebagai lembaga pelaksana pemeriksaan pangan yangdinyatakan halal, yang dikemas untuk diperdagangkan di Indonesia. ${ }^{12}$

Pelaksanaan kegiatan pemeriksaan pangan sebagaimana dimaksud dalam Pasal 1, meliputi :

a.pemeriksaan dan /atau verifikasi data pemohon; b.pemeriksaan proses produksi;

\footnotetext{
${ }^{9}$ Lihat Pasal 8 ayat (1), (2), dan (3) Keputusan Menteri Agama R.I. Nomor 518 Tahun 2001 Tanggal 30 Nevember 2001 tentangPedoman dan Tata Cara Pemeriksaan dan Penetapan Pangan Halal

${ }^{10}$ Lihat Pasal 9 ayat (1) dan (2) Keputusan Menteri Agama R.I. Nomor 518 Tahun 2001 Tanggal 30 Nevember 2001 tentangPedoman dan Tata Cara Pemeriksaan dan Penetapan Pangan Halal

${ }^{11}$ Lihat Pasal 10 ayat (1), (2), (3) dan (4) Keputusan Menteri Agama R.I. Nomor 518 Tahun 2001 Tanggal 30 Nevember 2001 tentangPedoman dan Tata Cara Pemeriksaan dan Penetapan Pangan Halal

${ }^{12}$ Lihat Pasal 1 Keputusan Menteri Agama Republik Indonesia Nomor 519 Tahun 2001 Tanggal 30 Nopember 2001 tentang Lembaga Pelaksana Pemeriksaan Pangan Halal
} 
c.pemeriksaan laboratorium;

d.pemeriksaan pengepakan, pengemasan dan pemyimpanan produk;

e.pemeriksaan sistem transportasi, distribusi, pemasaran dan penyajian;

f.pemrosesan dan penetapan Sertifikasi Halal. ${ }^{13}$

Sesuai ketentuan MUI, masa berlaku Sertifikat Halal adalah dua tahun.Selama masa tersebut, perusahaan harus dapatmemberikan jaminan kepada MUI dan konsumen Muslim bahwaperusahaan senantiasa menjaga konsistensi kehalalan produknya.Oleh karena itu LPPOM MUI mewajibkan perusahaan untukmenyusun suatu sistem yang disebut Sistem Jaminan Halal (SJH)dan terdokumentasi sebagai Manual SJH.Manual ini disusun olehprodusen sesuai dengan kondisi perusahaannya.Sertifikat Halal adalah fatwa tertulis yang dikeluarkan oleh MUIyang menyatakan kehalalan suatu produk yang merupakankeputusan sidang Komisi Fatwa MUI berdasarkan proses audityang dilakukan oleh LPPOM MUI. ${ }^{14}$ Prinsip-prinsip yang ditegakkan dalam operasional SJH adalah:

1. Maqoshidu syariah

Pelaksanaan SJH bagi perusahaan yang memiliki SH MUI mempunyai maksud memelihara kesucian agama, kesucian pikiran,kesucian jiwa, kesucian keturunan, dan kesucian harta.

2. Jujur

Perusahaan harus jujur menjelaskan semua bahan yang digunakan dan proses produksi yang dilakukan di perusahaan di dalam ManualSJH serta melakukan operasional produksi halal sehari-hariberdasarkan apa yang telah ditulis dalam Manual SJH.

3. Kepercayaan

LPPOM memberikan kepercayaan kepada perusahaan untuk menyusun sendiri Manual SJH nya berdasarkan kondisi nyatainternal perusahaan.

4. Sistematis

SJH didokumentasikan secara baik dan sistematis dalam bentuk Manual SJH dan arsip terkait agar bukti-bukti pelaksanaannya dilingkungan perusahaan mudah untuk ditelusuri.

5. Disosialisasikan

Implementasi $\mathrm{SJH}$ adalah merupakan tanggungjawab bersama dari level manajemen puncak sampai dengan karyawan, sehingga SJHharus disosialisasikan dengan baik di lingkungan perusahaan.

6. Keterlibatan key person

Perusahaan melibatkan personal-personal dalam jajaran manajemenuntuk memelihara pelaksanaan SJH.

7. Komitmen manajemen

\footnotetext{
${ }^{13}$ Lihat Pasal 2 Keputusan Menteri Agama Republik Indonesia Nomor 519 Tahun 2001 Tanggal 30 Nopember 2001 tentang Lembaga Pelaksana Pemeriksaan Pangan Halal

${ }^{14}$ Panduan Umum Sistem Jaminan HalalLppom - MUI, Loc.Cit.
} 
Implementasi SJH di perusahaan dapat efektif dilaksanakan jika didukung penuh oleh top manajemen.Manajemen harusmenyatakan secara tertulis komitmen halalnya dalam bentukkebijakan halal.

8. Pelimpahan wewenang

Manajemen memberikan wewenang proses produksi halalnya kepada auditor halal internal.

9. Mampu telusur

Setiap pelaksanaan fungsi produksi halal selalu ada bukti dalam bentuk lembar kerja yang dapat ditelusuri keterkaitannya.

10. Absolut

Semua bahan yang digunakan dalam proses produksi halal harus pasti kehalalannya. SJH tidak mengenal adanya status bahan yangberisiko rendah, menengah atau tinggi terhadap kehalalan suatuproduk.

\section{Spesifik}

Sistem harus dapat mengidentifikasi setiap bahan secara spesifik merujuk pada pemasok, produsen, dan negara asal.Ini berartibahwa setiap kode spesifik untuk satu bahan dengan satu statuskehalalan.

Berdasarkan uraian di atas, kewenangan MUI dalam memberikan jaminan produk halal sebelum lahirnya Undang-Undang Nomor 33 Tahun 2014tentangJaminan Produk Halal, sangatlah besar (Super Body) yang berjalan dalam kurun waktu yang cukup lama sekitar 25 (dua puluh lima) tahun lamanya. Namun Pelaksanaan Jaminan Produk Halal di Indonesia selama 25 tahun yang dilakukan oleh lembaga keulamaan LPPOM MUI, hanyalah berdasarkan oleh Keputusan Menteri Agama dan belum mempunyai payunghukum yang kuat yang mengatur standar kehalalandan lembaga sertifikasi yang memberikan kepastian dan jaminan hukum bagi masyarakatmuslim.

Sehingga sebagaimana penjelasan Undang-Undang Nomor 33 Tahun 2014tentangJaminan Produk Halalyaitu berkaitan dengan itu, dalam realitasnya banyak produk yangberedar di masyarakat belum semua terjamin kehalalannya.Sementara itu, berbagai peraturan perundang-undangan yangmemiliki keterkaitan dengan pengaturan produk halal belummemberikan kepastian dan jaminan hukum bagi masyarakatmuslim.

Oleh karena itu, pengaturan mengenai Jaminan Produk Halal perlu diatur dalam satu undang-undang yang secara komprehensif mencakupproduk yang meliputi barang dan/atau jasa yang terkait denganmakanan, minuman, obat, kosmetik, produk kimiawi, produkbiologi, dan produk rekayasa genetik serta barang gunaan yangdipakai, digunakan, atau dimanfaatkan oleh masyarakat.

\section{Pergeseran Kewenangan MUI Dalam Memberikan Jaminan Produk Halal Pasca Lahirnya Undang-Undang Nomor 33 Tahun 2014.}

Berdasarkan Penjelasan Undang-Undang Nomor 18 Tahun 2012 tentangPangan, menyatakan pangan adalah segala sesuatu yang berasal dari sumber hayati produk pertanian, perkebunan, kehutanan, perikanan, peternakan, perairan, 
dan air, baik yang diolah maupun tidak diolah yangdiperuntukkan sebagai makanan atau minuman bagi konsumsi manusia, termasuk bahan tambahanPangan, bahan baku Pangan, dan bahan lainnya yang digunakan dalam proses penyiapan, pengolahan,dan/atau pembuatan makanan atau minuman.

Penyelenggaraan Pangan dilakukan untuk memenuhi kebutuhan dasar manusia yang memberikanmanfaat secara adil, merata, dan berkelanjutan dengan berdasarkan pada Kedaulatan Pangan,Kemandirian Pangan, dan Ketahanan Pangan. Hal itu berarti bahwa dalam rangka memenuhi kebutuhankonsumsi pangan masyarakat sampai pada tingkat perseorangan, negara mempunyai kebebasan untukmenentukan kebijakan pangannya secara mandiri, tidak dapat didikte oleh pihak mana pun, dan parapelaku usaha pangan mempunyai kebebasan untuk menetapkan dan melaksanakan usahanya sesuaidengan sumber daya yang dimilikinya. Pemenuhan konsumsi pangan tersebut harus mengutamakanproduksi dalam negeri dengan memanfaatkan sumber daya dan kearifan lokal secara optimal. Untukmewujudkan hal tersebut, tiga hal pokok yang harus diperhatikan adalah (i) ketersediaan pangan yangberbasis pada pemanfaatan sumber daya lokal secara optimal, (ii) keterjangkauan pangan dari aspek fisikdan ekonomi oleh seluruh masyarakat, serta (iii) pemanfaatan pangan atau konsumsi pangan dan giziuntuk hidup sehat, aktif, dan produktif.

Pewujudan ketersediaan pangan yang berbasis pada pemanfaatan sumber daya lokal secara optimaldilakukan dengan penganekaragaman pangan dan pengutamaan produksi pangan dalam negeri.Pewujudan keterjangkauan pangan dari aspek fisik dan ekonomi dilakukan melalui pengelolaan stabilisasipasokan dan harga pangan pokok, pengelolaan cadangan pangan pokok, dan pendistribusian panganpokok. Pemanfaatan pangan atau konsumsi pangan dan gizi akan menghasilkan sumber daya manusiayang berkualitas sebagai salah satu faktor penentu keberhasilan pembangunan. Hal itu dilakukan melaluipemenuhan asupan pangan yang beragam, bergizi seimbang, serta pemenuhan persyaratan keamananpangan, mutu pangan, dan gizi pangan.

Sedangkan sejak lahirnya Undang-Undang Nomor 33 Tahun 2014tentangJaminan Produk Halal pengertian pangan diperluas menjadi produk adalah barang dan/atau jasa yang terkait dengan makanan, minuman, obat, kosmetik, produk kimiawi, produk biologi, produk rekayasa genetik, serta barang gunaan yang dipakai, digunakan, ataudimanfaatkan oleh masyarakat.Dalam konsideran UndangUndang Nomor 33 Tahun 2014tentangJaminan Produk Halal dijelaskan

a. bahwa Undang-Undang Dasar Negara Republik Indonesia Tahun 1945 mengamanatkan negaramenjamin kemerdekaan tiap-tiap penduduk untukmemeluk agamanya masing-masing dan untukberibadah menurut agamanya dan kepercayaannyaitu;

b. bahwa untuk menjamin setiap pemeluk agama untukberibadah dan menjalankan ajaran agamanya, negaraberkewajiban memberikan pelindungan dan jaminantentang kehalalan produk yang dikonsumsi dandigunakan masyarakat;

c. bahwa produk yang beredar di masyarakat belumsemua terjamin kehalalannya; 
d. bahwa pengaturan mengenai kehalalan suatu produkpada saat ini belum menjamin kepastian hukum danperlu diatur dalam suatu peraturan perundangundangan;

e. bahwa berdasarkan pertimbangan sebagaimanadimaksud dalam huruf $a$, huruf $b$, huruf c, dan hurufd perlu membentuk Undang-Undang tentang JaminanProduk Halal;

Pembentukan Undang-Undang Nomor 33 Tahun 2014tentangJaminan Produk Halal ini sebagaimana konsideran tersebut, telah memberikan kewenangan kepada lembaga yang telah ada sebelumnya dan lembaga bentukan baru.Menurut Miriam Budiardjo, sumber-sumber kewenangan, terdapat 3 (tiga) sumber kewenangan yaitu:

1. Sumber atribusi yaitu pemberian kewenangan pada badan atau lembaga / pejabat negara tertentu baik oleh pembentuk Undang-Undang Dasar maupun pembentuk Undang-Undang.Sebagai contoh : Atribusi kekuasaan presiden dan DPR untuk membentuk Undang-Undang.

2. Sumber delegasi yaitu penyerahan atau pelimpahan kewenanangan dari badan / lembaga pejabat tata usaha Negara lain dengan konsekuensi tanggung jawab beralih padapenerima delegasi.Sebagai contoh : Pelaksanaan persetujuan DPRD tentang persetujuan calon wakil kepala daerah.

3. Sumber mandat yaitu pelimpahan kewenangan dan tanggung jawab masih dipegang oleh sipemberi mandat.Sebagai contoh : Tanggung jawab memberi keputusan-keputusan oleh menteri dimandatkan kepada bawahannya. ${ }^{15}$

Kemudian Miriam Budiardjo menambahkan, dalam literatur ilmu politik, ilmu pemerintahan, dan ilmu hukum sering ditemukan istilah kekuasaan, kewenangan, dan wewenang.Kekuasaan sering disamakan begitu saja dengan kewenangan, dan kekuasaan sering dipertukarkan dengan istilah kewenangan, demikian pula sebaliknya.Bahkan kewenangan sering disamakan juga dengan wewenang. Kekuasaan biasanya berbentuk hubungan dalam arti bahwa ada satu pihak yang memerintah dan pihak lain yang diperintah. ${ }^{16}$

Menurut Jimly Asshiddiqie, Atribusi merupakan wewenang yang melekat pada suatu jabatan. Dalam tinjauan Hukum Tata Negara, atribusi ditunjukkan dalam wewenang yang dimiliki oleh organ pemerintah dalam menjalankan pemerintahannya berdasarkan kewenangan yang ditunjuk oleh pembuat undangundang.Kewenangan atribusi tersebut menunjukkan pada kewenangan asli atas dasar konstitusi.Kewenangan atribusi hanya dimiliki oleh DPR, Presiden, dan DPD dalam hal pembentukan undang-undang.Hasil produk dari ketiga lembaga Negara tersebut adalah undang-undang, oleh karena materi yang diatur dalam undang-undang hanya terbatas pada hal-hal yang bersifat umum saja, maka diperlukan bentuk-bentuk peraturan perundang-undangan yang lebih rendah (subordinate legislation) sebagai peraturan pelaksana undang-undang yang bersangkutan.

\footnotetext{
${ }^{15}$ Miriam Budiardjo, Dasar-Dasar Ilmu Politik, (Jakarta :Gramedia Pustaka Utama, 2008), hlm. 35.

${ }^{16} \mathrm{Ibid}, \mathrm{hlm} .36$
} 
Pemberian kewenangan untuk mengatur lebih lanjut mengenai teknis atau pelaksana dari undang-undang disebut denganpemberian kewenangan delegasi. Proses pendelegasian kewenangan regulasi atau legislasi inilah yang disebut sebagai pendelegasian kewenangan legislative atau "legislative delegation of rule making power" ${ }^{17}$ Pengaturan pendelegasian kewenangan dapat dilakukan dengan 3 alternatif syarat, yaitu: a. Adanya perintah yang tegasmengenai subjek lembaga pelaksana yang diberi delegasi kewenangan dan bentuk peraturan pelaksana untuk menuangkan materi pengaturan yang didelegasikan; b. Adanya perintah yang tegas mengenai bentuk peraturan pelaksana untuk menuangkan materi pengaturan yang didelegasikan; atau c. Adanya perintah yang tegas mengenai pendelegasian kewenangan dari undang-undang atau lembaga pembentuk undang-undang kepada lembaga penerima delegasi kewenangan, tanpa penyebutan bentuk peraturan yang mendapat delegasi. ${ }^{18}$

Ketiga syarat tersebut bersifat pilihan dan salah satunya harus ada dalam pemberian delegasi kewenangan pengaturan (rule-making power).Berbeda halnya dengan kewenangan delegasi maupun atribusi. Kewenangan mandat merupakan pemberian, pelimpahan, atau pengalihan kewenangan oleh suatu organ pemerintahan kepada pihak lain untuk mengambil keputusan atas tanggungjawab sendiri. ${ }^{19}$

Kewenangan Atribusi berdasarkan Undang-Undang Nomor 33 Tahun 2014tentangJaminan Produk Halaldiberikan kepada beberapa lembaga diantaranyaLembaga Pemeriksa Halal (LPH) dan Badan Penyelenggara Jaminan Produk Halal (BPJPH) dan Majelis Ulama Indonesia. Berdasarkan Pasal 6 UndangUndang Nomor 33 Tahun 2014tentangJaminan Produk Halal, ditegaskan dalam penyelenggaraan Jaminan Produk Halal, BPJPH berwenang:
a. merumuskan dan menetapkan kebijakan JPH;
b. menetapkan norma, standar, prosedur, dan kriteria JPH;
c. menerbitkan dan mencabut Sertifikat Halal dan Label Halal pada Produk;
d. melakukan registrasi Sertifikat Halal pada Produk luar negeri;
e. melakukan sosialisasi, edukasi, dan publikasi Produk Halal;
f. melakukan akreditasi terhadap LPH;
g. melakukan registrasi Auditor Halal;
h. melakukan pengawasan terhadap JPH;
i. melakukan pembinaan Auditor Halal; dan
j. melakukan kerja sama dengan lembaga dalam dan luar negeri di bidang penyelenggaraan JPH.
Dalam melaksanakan wewenang, BPJPH bekerja sama dengan: a. kementerian dan/atau lembaga terkait; b. LPH; dan c. MUI.Kerja sama BPJPH dengan kementerian dan/atau lembaga terkait dilakukan sesuai dengan tugas dan fungsi kementerian dan/atau lembaga terkait.Kerja sama BPJPH dengan LPH dilakukan untuk pemeriksaan dan/atau pengujian Produk. ${ }^{20}$ Kerja sama BPJPH

\footnotetext{
${ }^{17}$ Jimly Asshiddiqie, Perihal Undang-Undang, (Jakarta :Rajawali Pers, 2006), hlm. 148.

${ }^{18} \mathrm{Ibid}$, hlm. 266.

${ }^{19}$ Ibid, hlm. 264.

${ }^{20}$ Lihat Pasal 8 dan Pasal 9 Undang-Undang Nomor 33 Tahun 2014tentangJaminan Produk Halal
} 
dengan MUI dilakukan dalam bentuk: a. sertifikasi Auditor Halal; b. penetapan kehalalan Produk; dan c. akreditasi LPH. Penetapan kehalalan Produk dikeluarkan MUI dalam bentuk Keputusan Penetapan Halal Produk. ${ }^{21}$ BPJPH menetapkan LPH untuk melakukan pemeriksaan dan/atau pengujian kehalalan Produk. ${ }^{22} \mathrm{LPH}$ menyerahkan hasil pemeriksaan dan/ataupengujian kehalalan Produk kepada BPJPH.BPJPH menyampaikan hasil pemeriksaan dan/ataupengujian kehalalan Produk kepada MUI untuk memperoleh penetapan kehalalan Produk. ${ }^{23}$ Penetapan kehalalan Produk dilakukan oleh MUI.Penetapan kehalalan Produk dilakukan dalam Sidang Fatwa Halal.Keputusan Penetapan Halal Produk disampaikan kepada BPJPHuntuk menjadi dasar penerbitan Sertifikat Halal. ${ }^{24}$ Dalam hal Sidang Fatwa Halal menetapkan halalpada Produk yang dimohonkan Pelaku Usaha,BPJPH menerbitkan Sertifikat Halal. ${ }^{25}$

Dapat dipahami, tata cara memperoleh Sertifikat Halal diawali dengan pengajuanpermohonan Sertifikat Halal oleh Pelaku Usaha kepada BPJPH.Selanjutnya, BPJPH melakukan pemeriksaan kelengkapandokumen.Pemeriksaan dan/atau pengujian kehalalan Produkdilakukan oleh LPH. LPH tersebut harus memperoleh akreditasidari BPJH yang bekerjasama dengan MUI. Penetapan kehalalanProduk dilakukan oleh MUI melalui sidang fatwa halal MUIdalam bentuk keputusan Penetapan Halal Produk yangditandatangani oleh MUI.BPJPH menerbitkan Sertifikat Halalberdasarkan keputusan Penetapan Halal Produk dari MUItersebut.

Bagi konsumen, sertifikat halal sangatlah penting dan memiliki beberapa fungsi.Pertama, terlindunginya konsumen muslim dari mengonsumsi pangan, obatobatan dan kosmetika yang tidak halal; kedua, secara kejiwaan perasaan hati dan batin konsumen akan tenang; ketiga, mempertahankan jiwa dan raga dari keterpurukan akibat produk haram; dan keempat, akan memberikan kepastian dan perlindungan hukum.Bagi produsen, sertifikat halal mempunyai beberapa peran penting.Pertama, sebagai pertanggungjawaban produsen kepada konsumen muslim, mengingat masalah halal merupakan bagian dari prinsip hidup muslim; kedua, meningkatkan kepercayaan dan kepuasan konsumen; ketiga, meningkatkan citra dan daya saing perusahaan; dan keempat, sebagai alat pemasaran serta untuk memperluas area jaringan pemasaran; dan kelima, memberi keuntungan pada produsen dengan meningkatkan daya saing dan omzet produksi dan penjualan. ${ }^{26}$

Sertifikasi juga harus menjangkau bahan baku, bahan tambahan maupun bahan penolong dalam bentuk "bukan kemasan" yang tidak diecerkan untuk bahan

\footnotetext{
${ }^{21}$ Lihat Pasal 10 ayat (1) dan (2) Undang-Undang Nomor 33 Tahun 2014tentangJaminan Produk Halal

${ }^{22}$ Lihat Pasal 30 ayat (1) Undang-Undang Nomor 33 Tahun 2014tentangJaminan Produk Halal

${ }^{23}$ Lihat Pasal 32 ayat (1), dan (2) Undang-Undang Nomor 33 Tahun 2014tentangJaminan Produk Halal

${ }^{24}$ Lihat Pasal 33 ayat (1), (2), dan (6) Undang-Undang Nomor 33 Tahun 2014tentangJaminan Produk Halal

${ }^{25}$ Lihat Pasal 34 ayat (1) Undang-Undang Nomor 33 Tahun 2014tentangJaminan Produk Halal

${ }^{26}$ Muhammad Ibnu Elmi As Pelu, Label Halal: Antara Spiritualitas Bisnis dan Komoditas Agama, (Malang: Madani, 2009), hlm. 31-55
} 
produk makanan, minuman, obat-obatan, kosmetik, dan produk lainnya yang beredar di masyarakat. ${ }^{27}$ Sertifikasi produk halal diberlakukan tidak hanya terhadap produk dalam negeri tetapi juga produk luar negeri.Mengenai produk yang bersertifikat halal dari lembaga sertifikat luar negeri, perlu diperhatikan bahwa tidak semua standar luar negeri atau internasional dapat diterapkan di Indonesia karena di Indonesia batasan halal adalah yang paling ketat dan tidak dapat disimpangi.Misalnya di luar negeri babi yang telah berubah menjadi $\mathrm{X}$ dapat menjadi tidak diharamkan lagi, sedangkan di Indonesia babi yang telah mengalami perubahan apapun tetaplah diharamkan. ${ }^{28}$

Berdasarkan penjelasan tersebut, sehingga Kasubdit Produk Halal Kemenag Siti Aminah membantah kabar yang beredar bahwa sertifikasi produk halal yang biasa ditangani oleh Majelis Ulama Indonesia (MUI) kini diambil alih sepenuhnya oleh Kementerian Agama (Kemenag).Dia juga menegaskan, MUI masih berperan besar dalam menentukan sertifikasi halal sebuah produk.MUI tetap berperan, sertifikasi halal itu tidak bisa dikeluarkan oleh Kementerian Agama tanpa adanya fatwa Keputusan Penetapan Kehalalan Produk dari MUI," kata Siti Aminah kepada detikcom. Siti menjelaskan secara singkat tentang proses penetapan sertifikasi halal produk. Masyarakat yang ingin mendapatkan sertifikat label halal harus mendaftar ke Badan Penyelenggara Jaminan Produk Halal (BPJPH) Kementerian Agama.

Badan ini kemudian meminta kepada LPH untuk melakukan audit atau pemeriksaan produk yang dimaksud. Siti Aminah menjelaskan, hasil audit LPH ini kemudian diserahkan kepada BPJPH. BPJPH kemudian menyampaikan hasil audit LPH itu ke MUI untuk dikeluarkan fatwa Keputusan Penetapan Kehalalan Produk. MUI lah yang kemudian menetapkan kehalalan produk itu lewat fatwa Keputusan Penetapan Kehalalan Produk.Surat ini kemudian diserahkan kembali ke BPJPH untuk kemudian dikeluarkan sertifikasi halal produk tersebut.Jadi, MUI tetap melakukan kegiatan itu.Lebih lanjut Siti Aminah menegaskan, justru kalau tidak ada fatwa Keputusan Penetapan Kehalalan Produk dari MUI itu, Kementerian Agama tidak bisa mengeluarkan sertifikasi halal. ${ }^{29}$

Terlihat, pasca pemberlakuan Undang-Undang Nomor 33 Tahun 2014tentangJaminan Produk Halal yang bertujuan memberikan kenyamanan, keamanan, keselamatan, dan kepastian ketersediaan Produk Halal bagi masyarakat dalam mengkonsumsi dan menggunakan Produk; dan meningkatkan nilai tambah bagi Pelaku Usaha untuk memproduksi dan menjual Produk Halal, memangMUI telah kehilangan hak dan kewenangan dalam pelaksanaan kegiatan pemeriksaan pangandan penerbitan sertifikasi halal seperti sebelumnya. Lembaga para alim ulama itu harus menyerahkan kewenangan menerbitkan sertifikasi halal kepada

${ }^{27}$ KN. Sofyan Hasan, Kepastian Hukum Sertifikasi Dan Labelisasi Halal Produk Pangan, Jurnal Dinamika Hukum Vol. 14 No. 2 Mei 2014, hlm. 230.

${ }^{28}$ Ma'ruf Amin, “Mengapa Keharaman Babi Bersifat Mut- lak”, Jurnal Halal, No.99 Thlm. XVI Tahun 2013, hlm. 46-47

${ }^{29}$ Ray Jordan, Ramai Soal Kemenag Ambil Alih Sertifikasi Halal dari MUI, ini Penjelasannya, http://news.detik.com/berita/d-3349741/ramai-soal-kemenag-ambil-alih-sertifikasi-halal-dari-muiini-penjelasannya, diunduh tanggal 1 april 2017. 
BPJPH.Dimana sebelumnya merupakan kewenangan sangat besar yang diemban oleh MUI.Meski demikian, MUI masih dilibatkan dalam pemberian fatwa halal maupun haram.Undang-Undang Nomor 33 Tahun 2014tentangJaminan Produk Halalyang disahkan Presiden Susilo Bambang Yudhoyono pada 17 Oktober 2014 itu, mengamanatkan pembentukan BPJPH paling lambat tiga tahun setelah UU disahkan atau pada 2017."Mochammad Jasin, Irjen Kementerian Agama menerangkan, Undang-Undang Nomor 33 tahun 2014memberikan payung hukum terhadap sertifikasi halal yang selama ini tidak memiliki regulasi”.

Berdasarkan Pasal 6huruf cUndang-Undang Nomor 33 tahun 2014 tentang Jaminan Produk Halal, yang mengatur tentang wewenang BPJPH, jelas disebut bahwa BPJPH berwenang menerbitkan dan mencabut sertifikat halal dan label halal pada produk.Selain soal kewenangan menerbitkan sertifikat halal, ada beberapa poin lain yang bakal menguntungkan pemerintah. Salah satunya, keberadaan BPJPH di bawah kendali Kementerian Agama yang bakal mempermudah pemerintah dalam melakukan audit."Selanjutnya Mochammad Jasin, Irjen Kementerian Agama, Audit bisa dilakukan atas permintaan menteri agama atau jika ada laporan dari masyarakat terhadap penyalahgunaan kewenangan.Jika diketahui BPJPH melakukan jual-beli sertifikat halal, maka Inspektorat Jenderal Kemenag bisa mengusutnya".Keuntungan lain, dana yang diperoleh dari sertifikasi halal bisa dimasukkan ke kas negara melalui jalur Penerimaan Negara Bukan Pajak (PNBP).

Oleh sebab itu, nantinya besaran tarif proses sertifikasi bakal ditetapkan oleh Kementerian Keuangan. "Mochammad Jasin, Irjen Kementerian Agama menambahkan selama ini aturannya tidak ada. Kita tidak tahu biaya (sertifikasi) tersebut masuk ke mana".Nurgina, Kepala Seksi Penyuluhan Produk Halal dan Pengawasan, Kementerian Agama menambahkan, terbentuknya BPJPH merupakan menjamin keamanan dan kenyamanan produk-produk asal Indonesia, baik di dalam maupun luar negeri."Pernah terjadi kasus, ada produk Indonesia yang tidak diterima negara luar karena yang sertifikasi adalah MUI.Mereka menganggap sertifikasi itu bukan bagian dari pemerintah sehingga ditolak.Jadi dengan adanya BPJPH, maka kita menjaga produk Indonesia di luar negeri”.

Penjelasan juga disampaikan Osmena Gunawan, Wakil Direktur Lembaga Pengkajian Pangan, Obat-obatan, Makanan dan Kosmetika, Majelis Ulama Indonesia (LPPOM MUI).Ia mengaku tidak mengetahui berapa besaran dana hasil sertifikasi halal. Namun, Osmena memberi sinyal pemasukan MUI berdasar besaran tarif yang harus dibayar oleh para pemilik produk. "Gambarannya, Rp 2,5 juta untuk sertifikasi halal. Kalau dua orang maka Rp 5 juta. Kalau yang daftar 100 orang, maka dikali saja Rp 2,5 juta," katanya mencoba menjelaskan secara sederhana.Apa yang disampaikan Osmena sesuai dengan SK Direktur LPPOM MUI Nomor: SK 04/Dir/LP POM MUI/XI/07 tentang Biaya Memperoleh Sertifikat Halal. Ketentuan itu menyebutkan, nominal biaya sertifikasi berkisar antara Rp2 juta sampai Rp4,5 juta per jenis produk. Sertifikasi itu hanya berlaku selama dua tahun dan harus terus diperbarui.

Penjelasan tambahan disampaikan Farid MS, Kepala Bidang Informasi dan Komunikasi MUI Pusat. Ia menjelaskan, selama setahun periode 2014-2015, MUI 
menerbitkan sertifikat halal nasional sebanyak 17.712 lembar untuk 145.981 produk, plus sertifikat halal luar negeri 846 lembar untuk 20.467 produk. Total sebanyak 18.558 lembar sertifikat untuk 166.448 produk.Jika diambil biaya rata-rata $\mathrm{Rp} 2,5$ juta per sertifikat halal, seperti disampaikan Osmena, artinya selama periode 20142015, MUI mendapat pemasukan Rp 46,4 miliar. Itu angka minimal.Angka tersebut bisa lebih besar. Berdasarkan SK 04/Dir/LP POM MUI/XI/07 tadi, ada klausul yang menyebut: "Apabila perusahaan mempunyai jenis produk lebih dari satu dalam satu sertifikat akan dikenakan biaya tambahan antara Rp 1,5 juta hingga Rp 3 juta”. ${ }^{30}$

Sumber lainnya menerangkan,dalam perkembangannya MUI banyak menemui kendala,terutama masalah kewenangan dan legitimasi.Hal ini dipicu oleh tidak adanya produk hukum yang jelas, yang mendukung MUI untuk menerbitkan sertifikasi halal. Masalah lain timbul ketika banyak produk yang telah bersertifikasi halal tetapi nyatanya haram. Seperti penemuan BPPOM pada produk daging dendeng atau abon.Meski secara jelas disebutkan daging sapi, hasil tes menunjukkan bahwa produk yang beredar adalah daging babi.Kelemahan MUI semakin bertambah dalam hal pengawasan.Dalam situs LPPOM MUI disebutkan mengenai biaya pengurusan sertifikasi halal. Berkisar antara Rp 500 ribu hingga $R p 2$ juta rupiah per produk (data terbaru menunjukkan hingga angka Rp 6 juta) ditambah penyediaan jasa penginapan, makanan, dan transportasi selama tim pemeriksa LPPOM MUI berada di lokasi pengolahan produk. Terlebih lagi tidak ada payung hukum dan undang-undang yang mengatur, sehingga standardisasi biaya ditetapkan secara sepihak oleh MUI. Keadaan semakin diperparah dengan tidak adanya audit aliran uang sertifikasi halal. ${ }^{31}$

Berdasarkan keterangansumber-sumber diatas, dimanasebelum lahirnya Undang-Undang Nomor 33 Tahun 2014terdapat beberapa kelemahan yang terhadap jaminan produk halaldiantaranya belum mempunyai payung hukum regulasi yang kuat yaitu belum adanya undang-undang yang mengatur terhadaplembaga yang memberikan jaminan produk halal mulai dari pemeriksaan sampai penerbitan sertifikat, fungsi pengawasan yang tidak jelas, dan dana yang diperoleh dari sertifikasi halal tidak trasparan. Kelemahan-kelemahan tersebut haruslahdiperbaiki, sehinggalahirnya Undang-undang Jaminan Produk Hukum bertujuan memberikan kenyamanan, keamanan, keselamatan, dan kepastian ketersediaan produk halal bagi masyarakat dalam mengonsumsi dan menggunakan produk dan meningkatkan nilai tambah bagi pelaku usaha untuk memproduksi dan menjual produk halal.Kenyamanan, keamanan, keselamatan, dan kepastian memang sangat dibutuhkan bagi setiap pelaku usaha dan konsumen.

Hal ini dikarenakan tuntutan kehidupan yang semakin kompleks dan modern tersebut memaksa setiap individu dalam masyarakat mau tidak mau, suka atau tidak

\footnotetext{
${ }^{30}$ Kukuh Bhimo Nugroho, Perebutan Sertifikasi Halal Awal Konflik MUIdenganPemerintah https://www.beritadumay.com/perebutan-sertifikasi-halal-awal-konflik-mui-denganpemerintah/diunduh tanggal 1 april 2017

${ }^{31}$ Lies Afroniyati, Tarik Ulur Kepentingan Sertifikasi Halal Oleh MUI, http://www.gusdurian.net/id/article/opini/Tarik-Ulur-Kepentingan-Sertifikasi-Halal-olehMUI/diunduh tanggal 1 april 2017
} 
suka menginginkan adanya kepastian, terutama kepastian hukum, sehingga setiap individu dapat menentukan hak dan kewajibannya dengan jelas dan terstruktur". ${ }^{32}$

Kepastian hukum adalah jaminan bahwa hukum dijalankan, bahwa yang berhak menurut hukum dapat memperoleh haknya dan bahwa putusan dapat dilaksanakan. Kepastian hukum merupakan perlindungan yustisiabel terhadap tindakan sewenang-wenang yang berati bahwa seseorang akan dapat memperoleh sesuatu yang diharapkan dalam keadaan tertentu.Hukum bertugas menciptakan kepastian hukum karena bertujuan untuk menciptakan ketertiban dalam masyarakat. Kepastian hukum merupakan ciri yang tidak dapat dipisahkan dari hukum terutama untuk norma hukum tertulis. Hukum tanpa nilai kepastian hukum akan kehilangan makna karena tidak lagi dapat dijadikan pedoman perilaku bagi semua orang. ${ }^{33}$ Sedangkan menurut M.Yahya Harahap,Kepastian hukum tersebut dalam masyarakat dibutuhkan demi tegaknya ketertiban dan keadilan. Ketidakpastian hukum akan menimbulkan kekacauan dalam kehidupan masyarakat, dan setiap anggota masyarakat akan saling berbuat sesuka hati serta bertindak main hakim sendiri. Keberadaan seperti ini menjadikan kehidupan berada dalam suasana kekacauan sosial. ${ }^{34}$

Kemudian berdasarkan penjelasan Undang-Undang Nomor 8 Tahun 1999tentangPerlindungan Konsumen bahwa perlindungan konsumen diselenggarakan sebagai usaha bersama berdasarkan 5 (lima) asasyang relevan dalam pembangunan nasional dimana salah satunnya juga menghendaki adanya kepastian hukum, yaitu sebagai berikut :

1. Asas manfaat dimaksudkan untuk mengamanatkan bahwa segala upaya dalampenyelenggaraan perlindungan konsumen harus memberikan manfaat sebesar-besarnyabagi kepentingan konsumen dan pelaku usaha secara keseluruhan.

2. Asas keadilan dimaksudkan agar partisipasi seluruh rakyat dapat diwujudkan secaramaksimal dan memberikan kesempatan kepada konsumen dan pelaku usaha untukmemperoleh haknya dan melaksanakan kewajibannya secara adil.

3. Asas keseimbangan dimaksudkan untuk memberikan keseimbangan antara kepentingankonsumen, pelaku usaha, dan pemerintah dalam arti materiil ataupun spiritual.

4. Asas keamanan dan keselamatan konsumen dimaksudkan untuk memberikan jaminanatas keamanan dan keselamatan kepada konsumen dalam penggunaan, pemakaian danpemanfaatan barang dan/atau jasa yang dikonsumsi atau digunakan.

\footnotetext{
${ }^{32}$ Moh. Mahfud MD, Membangun Politik Hukum, Menegakkan Konstitusi, (Jakarta : LP3S, 2006), hlm. 63 .

${ }^{33}$ Tata Wijayanta, Asas Kepastian Hukum, Keadilan Dan Kemanfaatan Dalam Kaitannya Dengan Putusan Kepailitan Pengadilan Niaga, Jurnal Dinamika Hukum Vol. 14 No. 2 Mei 2014, hlm. 220.

${ }^{34}$ M.Yahya Harahap, Pembahasan, Permasalahan dan Penerapan KUHAP, Edisi Kedua, (Jakarta : Sinar Grafika, 2006), hlm. 7.
} 
5. Asas kepastian hukum dimaksudkan agar baik pelaku usaha maupun konsumen menaatihukum dan memperoleh keadilan dalam penyelenggaraan perlindungan konsumen, sertanegara menjamin kepastian hukum. ${ }^{35}$

Berdasarkan uraian tersebut, dapat dikatakan bahwa regulasi yang ada tidak memberikan jaminan kepastian hukum terhadap produk pangan halal bagi konsumen muslim di Indonesia, sehingga pasca pemberlakuan Undang-Undang Nomor 33 Tahun 2014 tentang Jaminan Produk Halal, dimana undang-undang ini berangkat dari kelemahan-kelemahan sebelumnya, oleh karena itu kewenangan MUI yang super bodyyang meliputi pemeriksaan dan /atau verifikasi data pemohon, pemeriksaan proses produksi, pemeriksaan laboratorium, pemeriksaan pengepakan, pengemasan dan pemyimpanan produk, pemeriksaan sistem transportasi, distribusi, pemasaran dan penyajian dan pemrosesan dan penetapan Sertifikasi Halaltelah terkikis, bergeser dan dipersempit oleh keberadaan lembaga Pemerintah yaitu Lembaga Pemeriksa Halal (LPH) dan Badan Penyelenggara Jaminan Produk Halal (BPJPH). Sehingga kewenangan MUI pasca pemberlakuan Undang-Undang Nomor 33 Tahun 2014 tentang Jaminan Produk Halal,adalah hanya berupa penetapan kehalalan Produk dilakukan dalam Sidang Fatwa Halalatas penyampaikan hasil pemeriksaan dan/ataupengujian kehalalan Produk yang dilakukan oleh LPHdan BPJPH.

\section{Penutup}

Sebelum lahirnya Undang-Undang Nomor 33 Tahun 2014tentangJaminan Produk Halal, kewenangan MUI sangatlah besar (Super Body)yang meliputi pemeriksaan dan /atau verifikasi data pemohon, pemeriksaan proses produksi, pemeriksaan laboratorium, pemeriksaan pengepakan, pengemasan dan pemyimpanan produk, pemeriksaan sistem transportasi, distribusi, pemasaran dan penyajian dan pemrosesan dan penetapan Sertifikasi Halal. Kewenangan tersebut berjalan dalam kurun waktu yang cukup lama sekitar 25 (dua puluh lima) tahun lamanya. Lembaga LPPOM MUI tersebut juga hanyalah berdasarkan oleh Keputusan Menteri Agama dan belum mempunyai payunghukum yang kuat yang mengatur standar kehalalandan lembaga sertifikasi yang memberikan kepastian dan jaminan hukum bagi masyarakatmuslim.

Sedangkan pasca lahirnyaUndang-Undang Nomor 33 Tahun 2014tentangJaminan Produk Halal, kewenangan MUI yang superbodytelah dipersempit dan bergeser kepada lembaga bentukan Pemerintah di bawah Kementrian Agama yaitu BPJPH dan LPH yang dalam pelaksanaan kewenangannya bekerjasama dengan MUI. Dimana proses jaminan produk halal yaitu dimulai LPH menyerahkan hasil pemeriksaan dan/ataupengujian kehalalan Produk kepada BPJPH. BPJPH menyampaikan hasil pemeriksaan dan/ataupengujian kehalalan Produk kepada MUI untuk memperoleh penetapan kehalalan Produk.Penetapan kehalalan Produk dilakukan oleh MUI.Penetapan kehalalan Produk dilakukan dalam Sidang Fatwa Halal.Keputusan Penetapan Halal Produk disampaikan kepada BPJPHuntuk menjadi dasar penerbitan Sertifikat Halal.

\footnotetext{
${ }^{35}$ Lihat Pasal 2 Undang-Undang Nomor 8 Tahun 1999 tentang Perlindungan Konsumen
} 


\section{Daftar Pustaka \\ Buku:}

Aisjah Girindra, LPPOM MUI Pengukir Sejarah Sertifikasi Halal., LPPOM MUI, Jakarta, 2005

Anonimous, Panduan Umum Sistem Jaminan Halal Lppom - MUI, Lembaga Pengkajian Pangan Obat-Obatan Dan Kosmetika, Majelis Ulama Indonesia, Jakarta, 2008

Hernawan, Pentingnya Pencantuman Label Halal Dalam Kemasan Produk Pangan Sebagai Bentuk Perlindungan Hukum Bagi Konsumen Muslim, (Skripsi), Fakultas Hukum Universitas 17 Agustus 1945, Samarinda, 2013

Jimly Asshiddiqie, Perihal Undang-Undang, Rajawali Pers, Jakarta, 2006

Ma'ruf Amin, "Mengapa Keharaman Babi Bersifat Mut- lak", Jurnal Halal, No.99 Thlm. XVI Tahun 2013

Mahfud MD, Moh., Membangun Politik Hukum, Menegakkan Konstitusi, LP3S, Jakarta, 2006

Miriam Budiardjo, Dasar-Dasar Ilmu Politik, Gramedia Pustaka Utama, Jakarta, 2008

Muhammad Ibnu Elmi As Pelu, Label Halal: Antara Spiritualitas Bisnis dan Komoditas Agama, Madani, Malang, 2009

Sofyan Hasan, KN., Kepastian Hukum Sertifikasi Dan Labelisasi Halal Produk Pangan, Jurnal Dinamika Hukum Vol. 14 No. 2 Mei 2014

Tata Wijayanta, Asas Kepastian Hukum, Keadilan Dan Kemanfaatan Dalam Kaitannya Dengan Putusan Kepailitan Pengadilan Niaga, Jurnal Dinamika Hukum Vol. 14 No. 2 Mei 2014

Thobieb al-Asyhar, Bahaya Makanan Haram., Al Mawardi Prima, Jakarta, 2003

Tulus abadi, Tim Pengkajian Hukum Tentang Peran Serta Masyarakat Dalam Pemberian Informasi Produk Halal, Kementerian Hukum Dan Hak Asasi Manusia RI, Badan Pembinaan Hukum Nasional, Jakarta, 2011

Yahya Harahap, M., Pembahasan, Permasalahan dan Penerapan KUHAP, Edisi Kedua, Sinar Grafika, Jakarta, 2006

\section{Peraturan Perundang-undangan:}

Undang-Undang Nomor 8 Tahun 1999 tentangPerlindungan Konsumen

Undang-Undang Nomor 33 Tahun 2014TentangJaminan Produk Halal 
Volume 14, Nomor 1, Januari-Juni 2019

Keputusan Menteri Agama Republik Indonesia Nomor 518 Tahun 2001 Tanggal 30 Nevember 2001 tentangPedoman dan Tata Cara Pemeriksaan dan Penetapan Pangan Halal

Keputusan Menteri Agama Republik Indonesia Nomor 519 Tahun 2001 Tanggal 30 Nopember 2001 tentang Lembaga Pelaksana Pemeriksaan Pangan Halal

\section{Internet}

Ainul Yaqin, Sekretaris Umum MUI Jawa Timur, https://www.hidayatullah.com/kajian/sejarah/read/2017/01/18/109939/sejara h-sertifikasi-halal-di-indonesia-1.html.diunduh tanggal 1 april 2017.

Ray Jordan, Ramai Soal Kemenag Ambil Alih Sertifikasi Halal dari MUI, ini Penjelasannya, http://news.detik.com/berita/d-3349741/ramai-soal-kemenag-ambil-alihsertifikasi-halal-dari-mui-ini-penjelasannya, diunduh tanggal 1 april 2017.

Kukuh Bhimo Nugroho, Perebutan Sertifikasi Halal Awal Konflik MUI dengan Pemerintahhttps://www.beritadumay.com/perebutan-sertifikasi-halal-awalkonflik-mui-dengan-pemerintah/diunduh tanggal 1 april 2017.

Lies Afroniyati, Tarik Ulur Kepentingan Sertifikasi Halal Oleh MUI, http://www.gusdurian.net/id/article/opini/Tarik-Ulur-KepentinganSertifikasi-Halal-oleh-MUI/ diunduh tanggal 1 april 2017.

Arif Kurnia, https://www.hpainternational.org/2017/03/06/sejarah-lppom-muidan-sertifikasi-halal-di-indonesia/, diunduh tanggal 1 april 2017. 